University of Michigan Law School

University of Michigan Law School Scholarship Repository

\title{
Behaviorally Informed Regulation
}

\author{
Michael S. Barr \\ University of Michigan Law School, msbarr@umich.edu
}

\section{Sendhil Mullainathan}

\section{Eldar Shafir}

Available at: https://repository.law.umich.edu/book_chapters/84

Follow this and additional works at: https://repository.law.umich.edu/book_chapters

Part of the Banking and Finance Law Commons, Consumer Protection Law Commons, Law and Psychology Commons, and the Law and Society Commons

\section{Publication Information \& Recommended Citation}

Barr, Michael S. "Behaviorally Informed Regulation." S. Mullainathan and E. Shafir, co-authors. In Behavioral Foundations of Public Policy, edited by E. Shafir, 440-64. Princeton: Princeton University Press, 2012.

This Book Chapter is brought to you for free and open access by the Faculty Scholarship at University of Michigan Law School Scholarship Repository. It has been accepted for inclusion in Book Chapters by an authorized administrator of University of Michigan Law School Scholarship Repository. For more information, please contact mlaw.repository@umich.edu. 


\section{Behaviorally Informed Regulation}

MICHAEL S. BARR

SENDHIL MULLAINATHAN

ELDAR SHAFIR
Policy makers typically approach human behavior from the perspective of the rational agent model, which relies on normative, a priori analyses. The model assumes people make insightfiul, well-planned, highly controlled, and calculated decisions guided by considerations of personal utility. This perspective is promoted in the social sciences and in professional schools and has come to dominate much of the formulation and conduct of policy. An alternative view, developed mostly through empirical behavioral re. search, and the one we will articulate here, provides a substantially different perspective on individual behavior and its policy and regulatory implications According to the empirical perspective, behavior is the amalgam of perceptions, impulses, judgments, and decision processes that emerge from the impressive machinery that people carry behind the eyes and between the ears. Actual human behavior, it is argued, is often unforeseen and misunderstood by classical policy thinking. A more nuanced behavioral perspective, it is suggested, can yicld deeper understanding and improved regulatory insight.

For a motivating example, consider the recent mortgage crisis in the United States. While the potential causes are myriad, a central problem was that many borrowers were offered and took out loans that they did not understand and could not afford, with disastrous results for the borrovers, financial firms, and the national economy. Borrowers, like most people, are not well described by the rational agent model. At the same time, we argue, a behavioral perspective that focuses only on the individual is incomplete for policy purposes. In some contexts, firms have strong incentives to exploit consumer biases and will shape their conduct in response not only to the behavior of consumers but also to the actions of regulators. Thus, policy also needs to take into account market contexts and the incentives and behaviors that they afford firms.

In what follows, we will outline some of the main research underpinning the behavioral perspective pertinent to regulation. We will explore how firms interact with consumers in different market contexts and will propose a model for understanding this interaction. We will then develop an analytic framework for behaviorally informed regulation and conclude with examples of relevant policy applications.

\section{On Behavior}

In contrast with the classical theory, which is driven by rational agents who make well-informed, carefully considered, and fully controlled choices, bchavioral research has shown that individuals depart from this decision-making model in important ways. Among other things, the availability and dissemination of data do not always lead to effective communication and knowledge; understanding and intention do not necessarily lead to the desired action; and purportedly inconsequential contextual nuances, whether intentional or not, can shape behavior and alter choices, often in ways that people themselves agree diminish their well-being in unintended ways. Individuals often exhibit temporal biases and misforecast their own behavior. By way of illustration, we will highlight how context, decisional conflict, mental accounting, knowledge and attention constraints, and institutions, shape individual decisions and behavior.

\section{Context}

Human behavior turns out to be heavily context dependent, a function of both the person and the situation. One of the major lessons of modern psychological research is the impressive power that the situation exerts, along with a persistent tendency to underestimate that power relative to the presumed influence of intention, education, or personality traits. In his now-classic obedience studies, for example, Milgram (1974) showed how decidedly mild situational pres- 
sures sufficed to generate persistent willingness, against thcir own wishes, on the part of individuals to administer what they believed to be grave levels of electric shock to innocent subjects. Along similar lines, Darley and Batson (1973) recruited seninary students to deliver a practice sermon on the parable of the Good Samaritan. Whilc half the seminarians were told they had plenty of time, others were led to believe they were running late. On their way to give the talk, all participants passed an ostensibly injured man slumped in a doorway groaning. Whereas the majority of those with time to spare stopped to help, a mere $10 \%$ of those who were running late stopped, while the remaining $90 \%$ stepped over the victim and rushed along. In contrast with these people's ethical training, scholarship, and presumed character, the contextual nuance of a minor time constraint proved decisive in the decision of whether to stop to hclp a suffering man. The powerful impact of context on behavior, we argue, increases the importance of etfective regulation and regulators' responsibility to assess effectiveness in policy contexts.

Context is made all the more important because an individual's predictions about her behavior in the future are often made in contexts different from those in which the individual will later find herself. Kochler and Poon (2005; See Lewin, 1951) argued that people's predictions of their future behavior overweight the strength of their current intentions and underweight the contextual factors that influence the likelihood that those intentions will translate into action. This imbalance can generate systematically misguided plans among consumers, who, reassured by their good intentions, procced to put themselves in ill-conceived situations that are powerful enough to make them act and choose otherwisc.

\section{Decisional Conflict}

Three decades of behavioral research have led to the notion that people's preferences are typically constructed, not merely revealed, during the decision making process (Lichtenstein and Slovic, 2006). The construction of preferences is heavily influenced by the nature and the context of decision. For example, the classical view of decision making docs not anticipate that decisional conflict will influcnce the making of decisions. Each option, according to the classical view, is assigned a subjective value, or "utility," and the person then proceeds to choose the option assigned the highest utility. A direct consequence of this account is that offering more alternatives is always a good thing, since the more options there are, the more likely is the consumer to find onc that proves sufficiently attractive.
In contrast to this model, behavioral rescarch sug gests that, since preferences tend to be constructed in the context of decision, choices can prove difficult to makc. People often search for a compclling rationale for choosing one option over another. Whereas sometimes a compelling reason can be articulated, at other times no easy rationale presents itself, rendering the conflict betiveen options hard to resolve. Such conflict can lead to the postponing of decision or to a passive resort to a "default" option and can generate preference patterns that are fundamentally different from those predicted by accounts based on valuc maximization. In particular, the addition of options can excessively complicate (and, thus, "worsen") the of fered set, whereas the normative rational choice assumption is that added options only make things better (Iyengar and Lepper, 2000; Shafir, Simonson, and Tversky, 1993; Tversky and Shafir, 1992).

In one study, for example, expert physicians had to decide about medication for a patient with osteoarthritis. These physicians were more likely to decline prescribing a new medication when they had to choose between two new medications than when only one new medication was available (Redelncier and Shafir, 1995). The difficulty of choosing between the two medications presumably led some physicians to reconmend not starting either. A sinilar pattern was documented with shoppers in an upscale grocery store, where tasting booths of fered the opportunity to taste 6 different jams in one condition, or any of 24 jams in the second condition. Of those who stopped to taste, $30 \%$ procceded to purchase a jam in the 6 jams condition, whercas nore stopped but only $3 \%$ purchased a jam in the 24-jam condition (Iyengar and Lepper, 2000). Of even greater relevance to the topic at hand, Iyengar, Jiang, and Huberman (2004) showed that employees' participation in $40 \mathrm{l}(\mathrm{k}$ ) plans drops as the number of fund options nade available by their employer increases.

Bertrand et al. (2010) conducted a field experiment with a local lender in South Africa to assess the relative inportance of various subtle psychological manipulations in the decision to take up a loan offer. Clients were sent letters offering large, short-term loans at randomly assigned interest rates. In addition, scveral psychological features on the offer letter were also independently randomized, one of which was the number of sample loans shown: the offer letters displayed either one example of a loan size and term, along with respective monthly repayments, or it displayed four such examples. In contrast with standard economic thinking and in line with conflictbased predictions, higher take-up was observed under the onc-option description than under the multipleoptions version. The magnitude of this effect was 
large: relative to the multiple-options version, the single-option description had the same positive effect on take-up as dropping the monthly interest on these loans by more than 2 percentage points.

\section{Mental Accounting}

In their intuitive mental accounting schemes, people compartmentalize wealth and spending into distinct budget categories, such as savings, rent, and entertainment, and into separate mental accounts, such as current income, assets, and future incoine (Thaler, 1985; 1992). Contrary to standard fungibility assumptions, people exhibit different degrees of willingness to spend from their diverse accounts. Compartmentalization can scrve useful functions in managing one's behavior, but it also can yield consumption patterns that are overly dependent on current income and sensitive to labels, which can lead to saving (at low interest rates) and borrowing (at higher rates) at the same time (Ausubel, 1991).

An understanding of such proclivities may help firms design instruments that bring about more desirablc outcomes. For instance, with respect to retirement saving, the tendency to spend one's savings is lower when monies are not in transaction accounts. And faulty planning, distraction, and procrastination all account for the persistent findings that saving works best as a default. Participation in $40 \mathrm{l}$ (k) plans is significantly higher when employers offer automatic enrollment (Madrian and Shea, 2001), and because participants tend to retain the default contribution rates and have an easier time committing now to a costly step in the future, savings can be increased as a result of agreeing to increased deductions from future raises (Benartzi and Thaler, 2004; sec also Benartzi, Peleg, and Thaler, this volume).

\section{Knowledge and Attention}

Standard theory assumes that consumers are attentive and knowledgeable and typically able to gauge and avail themselves of important information. In contrast, research suggests that many individuals lack knowledge of relevant options, program rules, benefits, and opportunities, and not only among the poor or the uneducated. Surveys show that less than one-fifth of investors (in stocks, bonds, finds, or other securities) can be considered "financially literate" (Alexander, Jones, and Nigro, 1998), and similar findings describe the understanding shown by pension plan participants (Schultz, 1995). Indeed, even older beneficiaries often do not know what kind of pension they are set to receive, or what mix of stocks and bonds are held in their retirement accounts (Lusardi, Mitchell, and Curto, 2009).

The amount of information people can and do at tend to is limited. Moreover, cognitive load has been shown to affect performance in everyday tasks. To the extent that consumers find themselves in challenging situations that are unfamiliar, tense, or distracting, all of which consume cognitive resources, less focused attention will be available to process the information that is relevant to the decision at hand. This, in turn, can render decision making even more dependent on situational cues and peripheral considerations, all the more so for "low literate" participants, who tend to experience even greater difficulties with effort versus accuracy trade-offs, show overdependence on peripheral cues, and tend toward a systematic withdrawal from many market interactions (Adkins and Ozannc, 2005).

Information cannot be thought of as naturally yielding knowledge, and knowledge cannot be assumed to generate the requisite behavior. People often do not fully process data that is imminently available because of limitatiens in attention, understanding, perceived relevance, misremembering, or misforecasting its impact. This is often underappreciated by program designers, who tend to believe that people will know that which is important and knowable. In summary, for participants with limited cognitive resourceswhose decisions are heavily dependent on insufficient knowledge, perceived norms, automatic defaults, and other minor contextual nuances-regulation merits even greater attention with regard to nuanced bchavioral factors.

\section{The Power of Institutions}

The substantial influence of context on behavior implies, among other things, that institutions will come to play a central role in shaping how people think and what they do. By institutions, we mean formal laws and rules, firms and other organizations, structures and governments, and widespread market practices (see, e.g., Sherraden and Barr, 2005). Among other things,

1. Institutions shape defaults, the "favored" starting point. It is now well established that defaults can have a profound influence on the outcomes of individual choices. Data available on decisions ranging from retirement savings and portfolio choices to the decision to be a willing organ donor illustrate the substantial increase in market share of default options (Johnson and Goldstein, 2003; Johnsøn et al., 1993; see in this volume, Johnson and Goldstein; Benartzi, P'eleg, and Thaler). Contrary to a view where the 
default is just one of a number of alternatives, in reality defaults persist. This persistence not only stems from confusion about available options, procrastination, forgetting, and other sources of inaction, but also may be fostered because the default is perceived as the most popular option (often a self-fulfilling prophecy), is implicitly recommended by experts, or is endorsed by the government.

2. Institutions shape behavior. Many low-income families are, de facto, savers, whether or not they resort to banks. But the availability of institutions to help foster savings can make a big difference (Barr, 2004; Berry, 2004). Without the help of a financial institution, people's savings are at risk (including from theft, impulse spending, and the needs of other household members), savings grow more slowly, and they may not be available as an emergency cushion or to support access to reasonably priced credit in times of need. Institutions provide safety, guidance, and control. In circumstances of momentary need, temptation, distraction, or limited self-control, those savers who are unbanked are likely to find it all the more difficult to succeed on the path to long-tern financial stability.

Consider, for example, two individuals with no access to credit cards: one has her paycheck directly deposited into a savings account, and the other does not. Whcreas cash is not readily available to the first person, who needs to take active steps to withdraw it, cash is immediately available to the second, who must take active measures to save it. The greater tendency to spend cash in the wallet compared to funds deposited in the bank (Thaler, 1999) suggests that the first, banked person will spend less on impulse and save more easily than the person who is unbanked. Holding risk- and savings-related propensities constant, the first person is likely to end up a more active and efficient saver than the second, due to nothing but a seemingly minor institutional arrangement.

Direct deposit is an institution that can have a profound effect on saving. A recent survey conducted by the American Payroll Association (2002) suggests that American employees are gaining confidence in direct deposit as a reliable method of payment that gives them greater control over their finances, and that employers are recognizing direct deposit as a low-cost employec benefit that can also save payroll processing time and money. The employers of the poor, in contrast, often do not require nor propose electronic sal. ary payments. Instead, they prefer not to offer dircct deposit to hourly/nonexempt employces, temporary or seasonal employees, part-timers, union employees, and employees in remote locations, all categories that correlate with being low paid. The most frequently stated reasons for not offering direct deposit to these employees include lack of processing time to meet standard industry (Automated Clearing House) requirements, high turnover, and union contract restrictions. All this constitutes a missed opportunity to offer favorable access to direct deposit for needy individuals, whose de facto default consists of going after hours to cash their modest check for a hefty fec.

3. Institutions provide implicit planning. As it turns out, a variety of institutions provide implicit planning, often in ways that address potential behavioral weaknesses. Credit card companies send customers timely reminders of due payments, and clients can elect to have their utility bills automatically charged, allowing them to avoid late fees if occasionally they do not get around to paying in time. The low-income buyer, on the other hand, without the credit card, the automatic billing, or the web-based reminders, risks missed payments, late fees, disconnected utilities (followed by high reconnection charges), etc. In fact, institutions can also sabotage planning, for example, by providing debt too easily. Temporal discounting in general and present bias in particular can be exploited to make immediate cash more attractive than any menacing future costs.

A behavioral analysis yields new appreciation for the impact of institutions, which affect people's lives by, among other things, easing their planning, helping them transform their intentions into actions, or enabling their resistance to temptation. Consider again the case of a low-income household. Having little slack, low-income households cannot readily cut back consumption in the face of an unanticipated need or shock (Mullainathan and Shafir, 2009). When they do cut back, it is often on essentials. In many instances, cutting back means paying late, and paying late means incurring costly late fees, utility or phone reconnection fees (Edin and Lein, 1997), and serious disruptions to work, education, and family life. In other cases it means costly short-term borrowing to avoid those consequences. In principle, the lack of slack should provide low-income households a strong incentive to increase their buffer-stock savings to cope with a volatile environment. Yet sucly households tend to have negligible liquid savings, in part because the financial system makes it difficult for them to get access to affordable savings vehicles (Barr, 2004).

Financial services may provide an important pathway out of poverty. Such services facilitate savings to mitigate shocks and promote asset development, and they facilitate borrowing to purchase higher-cost durables or to help weather tough times. In short, financial services allow individuals to smooth consumption and invest. Improvement of financial services, then, 
provides two key advantages. First, for individuals who have access to financial scrvices, improvement would lower the costs they pay. For example, improved financial services may cnable them to use a credit card rather than a more expensive payday lender. Second, individuals who have not had access to financial services would get the direct benefits of access, such as the ability to borrow to smooth shocks (c.g., an illness, job loss, or divorce).

Access to financial institutions allows people to improve their planning by keeping money out of temptation's way. Dircect deposit and automatic deductions can remove the immediate availability of cash and put in place automatic savings. Financial institutions can make it easy for individuals to make infrequent, carefully considered financial accounting decisions that can prove resistant to occasional intuitive error or t• momentary impulse. In this sense, improved financial institutions can have a disproportionate impact on the lives of the poor. Moving from a payday lender and a check casher to a bank with direct deposit and payroll deduction can have benefits in the form of improved planning, saving, temptation avoidance, and other outcomes far morc important than the transaction costs saved.

\section{Behavior, Markets, and Policy: A Conceptual Framework}

A behavioral perspective provides a better account of how individuals make decisions and is thus a useful corrective to the rational agent model. Yet a model focused on individuals is, on its own, incompletc as a basis for policy. The perspective outlined above needs to be embedded in the logic of markets. A framework is required that takes into account firms' incentives with respect to individual behavior as well as to regulation. This perspective produces two dimensions to consider: firms' interactions with consumers, and firms' interactions with regulators.

As for the first, the psychological biases of individuals can either be aligned with, or in opposition to, the interest of frms that market products or services. Consider a consumer who does not fully appreciate the profound effects of the compounding of interest. This consumer would be prone both to undersave and to overborrow. And both the consumer and society would prefer that he did not have such a bias in both contexts. Firms, for their part, would also prefer that the individual not have the bias to undersave, so that funds intended for investment and for fee gencration would not diminish (abstracting from fee structures). However, at least over the short term, firms would be perfectly content to see the same individual overborrow (abstracting from collection costs).

With regard to the second dimension, the market response to individual failure can profoundly affect regulation. In attempting to boost participation in 401 ( $k$ ) retirement plans, for example, the regulator faces at worst indifferent and at best positively inclined employers and financial firms. ${ }^{1}$ With respect to credit, by contrast, firms often have strong incentives to exacerbate psychological biases by failing to highlight the costs of borrowing. Regulation in this case faces a much more difficult challenge than in the savings situation. In forcing the disclosure of hidden prices of credit, the regulator often faces uncooperative firms, whose interests are to find ways to work around or undo regulatory interventions.

The mode of regulation chosen should take account of this interaction betiveen firms and individuals and between firms and regulators. One might think of the regulator as holding two kinds of levers, which we describe as changing the rules and changing the scoring. ${ }^{2}$ When forcing disclosure of the $\mathrm{APR}$, for example, the regulator cffectively changes the "rules" of the game: what a firm must say. A stronger form of rule change is product regulation: changing what a firm must do. Bchavioral rule changes, such as creating a favored starting position or default, fall somewhere in between. When imposing liability, by contrast, the regulator changes the way the game is "scored." Liability levels can be set, in theory, to match or exceed the gains to the firm from engaging in the disfavored activity. Scoring can also be changed, for cxample, by providing tax incentives to engage in the favored activity or by imposing negative tax consequences for engaging in a disfavored activity. Typically, changing the rules of the game (without changing the scoring) alters certain behaviors while maintaining the firms' original incentives; changing the scoring of the game can alter those incentives.

Understanding the interaction between individuals, firms, and regulators in particular markets highlights the care that must be taken when transferring behavioral economic insights from one domain to another. For example, the insights of the most prominent example of bchavioral regulation - setting defaults in 401 (k) participation - ought not to be mindlessly applicd to other markets. Changing the rules on retirement saving by introducing defaults works well because employers' incentives align (or do not misalign) with regulatory efforts to guide individual choice. In other words, under current conditions, employers are unaffected, or may even be hurt, by individuals' propensity to undersave in $\mathbf{4 0 l}(\mathrm{k})$ plans. ${ }^{3}$ Consequently, they will not lean against attempts to fix that problem. 
In other instances, where firms' incentives misalign with regulatory intent, changing the rules alone may not work since those firms have strong incentives to work creatively around those changes. Interestingly, such circumstances may lead to regulations, such as "changing the scoring" with liability, which, although deeply motivated by behavioral considerations, are not themselves particularly psychological in nature. That is, given market responses, rules based on subtle attempts to influence individual psychology, for example through defaults or framing, may be too weak, and changes in liability rules or other measures may prove necessary.

The distinction in market responses to individual psycholegy is central to our framework and is illustrated in table 26.1. In some cases, the market is either neutral or wants to overcome consumer fallibility. In other cases, the market would like to exploit or exaggerate consumer fallibility. When consumers misunderstand compounding of interest in the context of saving, banks have incentives to reduce this misunderstanding so as to increase deposits. When consumers misunderstand compounding in the context of borrowing, lenders may lack the incentive to correct this misunderstanding because they can induce consumers to overborrow in ways that maintain or enhance profitability, at least over market-relevant time horizons. ${ }^{4}$ When consumers procrastinate in signing up for the Earned Income Tax Credit (and hence in filing for taxes), private tax preparation firms have incentives to help remeve this procrastination so as to increase their customer base. When consumers procrastinate in returning rebates (but make retail purchases intending to get a rebate), retailers benefit. Note the parallelism in these examples: firms' incentives to alleviate or exploit a bias are not an intrinsic feature of the bias itself. Instead, they are a function of how the bias plays itself out in the particular market structure.
In the consumer credit market, one worrics that many interactions between individuals and firms are of the kind where firms seek to exploit, rather than alleviate, bias. If true, this raises the concern of overextrapolating from the $40 \mathrm{l}(\mathrm{k})$ defaults example to credit products. To the extent that $401(\mathrm{k})$ defaults work because the optimal behavior is largely aligned with market incentives, other areas, such as credit markets, might be more difficult to regulate with mere defaults. Furthermore, if the credit market is dominated by "low'road" firms offering opaque products that "prey" on human weakness, it is more likely that regulators of such a market will be captured because "high road" interests with small market share will tend to be too weak politically to push back against the bigger low-road players. Market forces will then defeat weak positive interventions, such as the setting of defaults, and low-road players will continue to dominate. Many observers, for example, believe that credit card markets were, at least prior to passage of the CARD Act in 2009, dominated by such low-road practices (see, e.g., Bar-Gill, 2004; Mann, 2007). If government policy makers want to attempt to use defaults in such contexts, they might need to deploy "stickier" defaults (namely, ones that might prove costly to abandon) or other more aggressive policy options.

In our conceptual approach to the issue of regulatory choice (table 26.2), the regulator can either change the rules of the game or change the scoring of the game. Setting a default is an example of changing the rules of the game, as is disclosure regulation. The rules of the game are changed when there is an attempt to change the nature of the interactions berween individuals and firms, as when the regulation attempts to affect what can be said, offered, or done Changing the scoring of the game, by contrast, changes the payoffs a firm will receive for particular outcomes. This may be done without a particular rule

Table 26.1 The firm and the individual

\begin{tabular}{lll}
\hline \hline Behavioral fallibility & $\begin{array}{l}\text { Market neutral and/or wants to } \\
\text { overcome consumer fallibility }\end{array}$ & Market exploits consumer fallibility \\
\hline $\begin{array}{l}\text { Consumers misunderstand } \\
\text { compounding }\end{array}$ & $\begin{array}{l}\text { Consumers misunderstand } \\
\text { compounding in savings }\end{array}$ & $\begin{array}{l}\text { Consumers misunderstand } \\
\text { compounding in borrowing }\end{array}$ \\
& $\rightarrow$ Banks would like to reduce & $\rightarrow$ Banks would like to exploit \\
this to increase savings base & this to increase borrowing \\
Consumers procrastinate & $\begin{array}{l}\text { Consumers procrastinate in } \\
\text { signing up for ElTC }\end{array}$ & $\begin{array}{l}\text { Consumers procrastinate in } \\
\text { returning rebates }\end{array}$ \\
& $\rightarrow$ Tax filing companies would & $\rightarrow$ Retailers would like to exploit \\
& like to reduce this so as to & this to increase revenues \\
& increase number of customers & \\
\hline
\end{tabular}


Table 26.2 Changing the game

\begin{tabular}{ll}
\hline \hline Rules & Set the defaults in $401(\mathrm{k})$ savings \\
& Opt-out rule for organ donation \\
Scoring & $\begin{array}{l}\text { Penalties for } 401(\mathrm{k}) \text { enrollment top } \\
\text { heavy with high-salary employees } \\
\end{array}$ \\
& Grants to states that enroll organ donors \\
\hline
\end{tabular}

about how the outcome is to be achieved. For examplc, pension regulation that penalizes firms whose $40 \mathrm{l}$ ( $\mathrm{k}$ ) plan enrollment is top-heavy with high-paid executives is an example of how scoring gives firms incentives to enroll low-income individuals without setting particular rules on how this is done. Changing rules and changing scoring often accompany each other, but they are conceptually distinct.

Table 26.3 weaves these approaches together, illustrating our conceptual framework for behaviorally informed regulation. The table shows how regulatory choice may be analyzed according to the market's stance toward human fallibility. On the left side of the table, market incentives align reasonably well with society's goal of overcoming consumer fallibility. Rules in that context may have a relatively lighter touch. For example, using automatic savings plans as a default in retirement saving, or providing for licensing and registration to ensure that standard practices are followed. Similarly, scoring on the left side of the table might involve tax incentives to reduce the costs to firms of engaging in behaviors that align well with their market interests and the public interest but may

Table 26.3 Behaviorally informed regulation

\begin{tabular}{|c|c|c|}
\hline & $\begin{array}{l}\text { Market neutral and/ } \\
\text { or wants to overcome } \\
\text { consumer fallibility }\end{array}$ & $\begin{array}{c}\text { Market exploits } \\
\text { consumer fallibility }\end{array}$ \\
\hline \multirow[t]{3}{*}{ Rules } & $\begin{array}{l}\text { Public education } \\
\text { on saving }\end{array}$ & $\begin{array}{l}\text { Sticky defaults } \\
\text { (opt-out mortgage or } \\
\text { credit card) }\end{array}$ \\
\hline & $\begin{array}{l}\text { Direct deposit/ } \\
\text { auto-save }\end{array}$ & $\begin{array}{l}\text { Information debiasing } \\
\text { (payoff time and cost for } \\
\text { credit cards) }\end{array}$ \\
\hline & Licensing & \\
\hline \multirow[t]{2}{*}{ Scoring } & $\begin{array}{l}\text { Tax incentives for } \\
\text { savings vehicles }\end{array}$ & $\begin{array}{l}\text { Ex post liability standard } \\
\text { for truth in lending }\end{array}$ \\
\hline & $\begin{array}{l}\text { Direct deposit } \\
\text { tax-refund accounts }\end{array}$ & $\begin{array}{l}\text { Broker duty of care and } \\
\text { changing compensation } \\
\text { practices (yield spread } \\
\text { premiums) }\end{array}$ \\
\hline
\end{tabular}

otherwise be too costly. On the right side of the table, by contrast, market incentives are largely misaligned with the public interest in overcoming consumer fallibility. In that context, rule changes will typically need to be more substantial to be effective and may need to be combined with changing the scoring.

The discussion that follows illustrates the challenge to policies in the top right-hand corner of table 26.3. Changing the rules of the game alone will often be insufficient when firms are highly motivated to find work-arounds. As such, merely setting a default - in contrast to defaults deployed in markets on the left side of the table-will likely not work. Thus, when we suggest opt-out policies in mortgages below, the challenge will be to find ways to make these starting positions "sticky" so that firms do not easily undo their default nature. In such cases, achieving an effective default may require separating low-road from high-road firms and making it profitable for highroad firms to offer the default product (for a related concept, sec Kennedy, 2005). For that to work, the default must be sufficiently attractive to consumers, sufficiently profitable for high-road firms to succeed in offering it, and the penalties associated with deviations from the default must be sufficiently costly so as to make the default stick even in the face of market pressures from low-road firms. In some credit markets, low-road firms may become so dominant that sticky defaults will be ineffectual. Moreover, achieving such a default is likely to be costlier than making defaults work when market incentives align, not least because the costs associated with the stickiness of the default involve greater dead-weight losses due to higher costs to opt out for those for whom deviating from the default is optimal. Such losses would need to be weighed against the losses from the current system, as well as against losses from alternative approaches, such as disclosure or product regulation. Nonetheless, given the considerations above, it seems worth exploring whether sticky defaults can help to transform consumer financial markets in certain contexts.

Sticky defaults are one of a set of examples we discuss as potential regulatory interventions based on our proposed conceptual framework. As noted above, given market responses to relevant psychological factors in different contexts, regulation may need to take a variety of forms, including some that, while perhaps informed by psychology, are designed not to affect behavioral change but rather to alter the market structure in which the relevant choices are made. Given the complexities involved, our purpose here is not to champion specific proposals but rather to illustrate how a behaviorally informed regulatory analysis may generate a deeper understanding of the costs and benefits of particular policies. 


\section{Behaviorally Informed Financial Regulation}

Following Barr, Mullainathan, and Shafir (2008a), we review a sct of ideas to illustrate our conceptual framework in three main areas of consumer finance: home mortgages, credit cards, and bank accounts. We will use these three substantive areas to explore how changing the rules and changing the scoring can affect firms' behavior in market contexts where firms have incentives to exploit consumer bias (as in credit) and in those where firms havc incentives to overcome such biases (as in saving). Our analyses map into different quadrants of table 26.3. Since we first published our work, there has becn significant progress in implementing a number of these ideas. ${ }^{5}$ We therefore also discuss how some of these ideas have been recently implemented in the CARD Act of 2009, the Dodd-Frank Wall Strect and Consumer Protection Act of 2010, and other policy initiatives. In addition, with the creation of the nciv Consumer Financial Protection Bureau (CFPB) in the Dodd-Frank Act, there is an opportunity to further learn from behavioral rescarch and to experiment with new approaches. Wc will briefly highlight some of these opportunitics.

\section{Behaviorally Informed Home Mortgage Regulation}

\section{FULL INFORMATION DISCLOSURE TO DEBIAS BORROWERS}

With the advent of nationwide credit reporting systems and the refincment of credit scoring and modeling, the creditor and broker know information about the borrower that the borrower does not neccssarily know about himsclf, including not just his credit score, but his likcly performance regarding a particular set of loan products. Creditors will know whether the borrower could qualify for a better, cheaper loan, as well as the likelihood that he will meet his obligations under the existing mortgage or become delinquent, refinance, default, or go into foreclosure. Yet lenders are not required to reveal this information to borrowers, and the impact of this lack of disclosure is probably cxacerbated by consumer beliefs. Consumers likcly have false background assumptions regarding what brokers and creditors reveal and the implications of their offers. What if consumers believe the following:

Creditors reveal all information about me and the loan products I am qualificd to receive. Brokers work for me in finding me the best loan for my purposes, and lenders offer me the best loans for which I qualify. I must be qualified for the loan I have been offcred, or the lender would not have validated the choice by offering me the loan.
Because I am qualified for the loan that must mean that the lender thinks that I can repay the loan. Why elsc would they lend me the money? Moreover, the government tightly regulates home mortgages; they make the lender give me all these legal forms. Surcly the government must regulate all aspects of this transaction.

In reality, the government does not regulate as the borrower belicves, and the lender does not necessarily bchave as the borrower hopes. Instead, information is hidden from the borrower, information that would improve market competition and outcomes. Given the consumer's probably falsc background assumptions and the reality of asymmetric information favoring the lender and broker, we suggest that creditors be required to reveal useful information to the borrower at the time of the mortgage loan offer, including disclosure of the borrower's credit score and the borrower's qualifications for the lender's mortgage products and rates. Such an apprach corresponds to the provision of dcbiasing information, in the top right of table 26.3.

The goal of these disclosures would be to put pressure on creditors and brokers to be honcst in their dealings with applicants. The additional information might improve comparison shopping and, perhaps, outcomes. Of course, revealing such information would also reduce brokers' and creditors' profit margins. But because the classic market competition model relies on full information and assumes rational behavior based on understanding, this proposal simply attempts to remove market frictions from information failures and to move market competition more toward its idcal. By reducing information asymmetry, full information disclosure would help debias consumers and lead to more competitive outcomes.

\section{EX POST STANDARDS-BASED TRUTH IN LENDING}

Optimal disclosure will not occur in all markets through competition alone becausc in many contexts firms have incentives to hidc information about products or prices and because consumers will not insist on competition based on transparency due to a lack of knowledge or understanding and a misforccasting of thcir ewn behavior. Competition under a range of plausible sccnarios will not necessarily generate psychologically informative and actionable disclosure. Moreover, even if all firms have an incentive to disclose in meaningful ways, they may not disclose in the same way, thus undermining comparison shopping by consumers. If competition does not produce informative disclosurc, disclosure regulation might be necessary. But the mere fact that disclosure regulation is needed does not mean that it will work. 
A behavioral perspective should focus in part on improving the disclosures themselves. The goal of disclosure should be to improve the quality of information about contract terms in meaningful ways. Simply adding information, for example, is unlikely to work. Disclosure policies are effective to the extent that they present a frame - a way of parsing the disclosurethat is both well understood and conveys salient information that helps the decision maker act optimally. It is possible, for example, that information about the failure frequency of particular products (" 2 out of 10 borrowers who take this kind of loan default") might help, but proper framing can be difficult to achieve and to maintain consistently, given that it may vary across situations. Moreover, the attempt to improve decision quality through better consumer understanding, which is presumed to change consumers' intentions, and consequently their actions, is fraught with difficulty. There is often a wide divide between understanding, intention, and action.

Furthermore, even if meaningful disclosure rules can be created, sellers can generally undermine whatever ex ante disclosure rule is established, in some contexts simply by "complying" with it: "Here's the disclosure form I'm supposed to give you, just sign here." With rules-based, ex ante disclosure requirements, the rule is set up first, and the firm (the discloser) moves last. While an ex ante rule may attempt to provide information and facilitate comparison shopping, whatever incentives the discloser had to confuse consumers persist in the face of the regulation. While officially complying with the rule, there is market pressure to find other means to avoid the salutary effects on consumer decisions that the disclosure was intended to achieve.

In light of the challenges inherent to addressing such issues ex ante, we propose that policy makers consider shifting away from sole reliance on a rulesbased, ex ante regulatory structure for disclosure as embodied in the Truth in Lending Act (TILA) and toward the integration of an ex post, standards-based disclosure requirement in addition. Rather than sole reliance on a rule, we would also deploy a standard, and rather than sole reliance on an ex ante decision about content, we would permit the standard to be enforced after the event, for example, after loans are made. In essence, courts or the new C.FPB would determine whether the disclosure would have, under common understanding, effectively communicated the key terms of the mortgage, conforming to some minimum standard, to the typical borrower. This approach could be similar to ex post determinations of reasonableness of disclaimers of warranties in sales contracts under UCC 2-316 (Uniform Commercial Code; see White and Summers, 1995). This type of policy intervention would correspond to a change in "scoring," as in the lower right of table 26.3.

An ex post version of truth in lending based on a reasonable-person standard to complement the fixed disclosure rule under TILA might permit innovation-both in products themselves and in disclosure-while minimizing rule evasion. An ex post standard with sufficient teeth could change the incentives of firms to confuse and would be more difficult to evade. Under the current approach, creditors can easily "evade" TILA by simultaneously complying with its actual terms while making the required disclosures of the terms effectively useless in the context of borrowing decisions by consumers with limited attention and understanding. TILA, for example, does not block a creditor from introducing a more salient term ("lower monthly cost!") to compete with the disclosed APR for borrowers' attention. By contrast, under an ex post standards approach, lenders could not plead mere compliance with a TILA rule as a defense. Rather, the question would be one of objective reasonableness: whether the lender meaningfully conveyed the information required for a typical consumer to make a reasonable judgment about the loan. Standards would also lower the cost of specification ex ante. Clarity of contract is hard to specify ex ante but easier to verify ex post. Over time, through agency action, guidance, model disclosures, no-action letters, and court decisions, the parameters of the reasonableness standard would become known and predictable.

While TILA has significant shortcomings, we do not propose abandoning it. Rather, TILA would remain and could be improved with a better understanding of consumer behavior. The Federal Reserve Board, for example, unveiled major and useful changes to its disclosure rules based on consumer research. ${ }^{\circ}$ TILA would still be important in setting uniform rules to permit comparison shopping among mortgage products, one of its two central goals. However, sonie of the burden of TILA's second goal, to induce firms to reveal information that would promote better consumer understanding even under circumstances in which the firm believes that it would hurt the firm, would be shifted to the ex post standard.

There would be significant costs to such an approach, especially at first. Litigation or regulatory enforcement would impose direct costs, and the uncertainty surrounding enforcement of the standard ex post might deter innovation in the development of mortgage products. The additional costs of compliance with a disclosure standard might reduce lenders' willingness to develop new mortgage products designed to reach lower-income or minority borrowers who might not be served by the firms' "plain vanilla" products. ${ }^{7}$ The lack of clear rules might also increase 
consumer confusion regarding how to compare innovative mortgage products to each other, even while it increases consumer understanding of the products being offered. Ultimately, if consumer confusion results mostly from firm obfuscation, then our proposal will likely help a good deal. By contrast, if consumer confiusion in this context results mostly from market complexity in product innovation, then the proposal is unlikely to make a major difference and other approaches focused on loan comparisons might be warranted (see, e.g., Thaler and Sunstcin, 2008, this volume).

Despite the shortcomings of an ex post standard for truth in lending, we believe that such an approach is worth pursuing. To limit the costs associated with our approach, the ex post determination of reasonableness could be significantly confined. For example, if courts are to be involved in enforcement, the ex post standard for reasonableness of disclosure might be limited to providing a (partial) defense to fill payment in foreclosure or bankruptcy, rather than being open to broader enforcement through affirmative suits for damages. Alternatively, rather than court enforcement, the ex post standard might be applied solely by the CFPB through supervision. Furthermore, the ex post exposure might be significantly reduced through ex ante steps. For example, the CFPB might develop safe harbors for reasonable disclosures, issue model disclosures, or use no-action letters to provide certainty to lenders. Moreover, firms might be tasked with conducting regular surveys of borrowers or conducting experimental design research to validate their disclosures; results from the research demonstrating a certain level of consumer understanding might provide a rebuttable presumption of reasonableness or even a safe harbor from challenge. ${ }^{8}$ The key is to give the standard sufficient teeth without deterring innovation. The precise contours of enforcement and liability arc not essential to the concept, and weighing the costs and benefits of such penalties, as well as detailed implementation design, are beyond the scope of introducing the idea here.

\section{STICKY OPT-OUT MORTGAGE REGULATION}

While the causes of the mortgage crisis are myriad, a central problem was that many borrowers took out loans that they did not understand and could not afford. Brokers and lenders offered loans that looked much less expensive than they really were, because of low initial monthly payments and hidden, costly features. Families commonly make mistakes in taking out home mortgages because they are misled by broker sales tactics, misunderstand the complicated terms and financial tradcoffs in mortgages, wrongly forecast their own behavior, and misperceive their risk of borrowing. How many homeowners really understand how the teaser rate, introductory rate, and reset rate relate to the I ondon Interbank Offered Rate plus some specified margin, or how many can judge whether the prepayment penalty will offset the gains from a teaser rate?

Altering the rules of the game of disclosure, and altering the "scoring" for seeking to evade proper disclosure, may be sufficient to reduce the worst outcomes. However, if market pressures and consumer confusion arc sufficiently strong, such disclosure may not be enough. If market complexity is sufficiently disruptive to consumer choice, product regulation might prove most appropriate. For example, by barring prepayment penalties, one could reduce lock-ins to bad mortgages; by barring short-term ARMs and balloon payments, one could reduce the pressure to refinance; in both cases, more of the cost of the loan would be pushed into interest rates, and competition could focus on an explicitly stated price in the form of the APR. Such price competition would benefit consumers, who would be more likely to understand the terms on which lenders were competing. Product regulation would also reduce cognitive and emotional pressures related to potentially bad decision making by reducing the number of choices and eliminating loan features that put pressure on borrowers to refinance on bad terms. However, product regulation may stifle beneficial innovation, and there is always the possibility that the government may simply get it wrong, prohibiting good products and permitting bad ones.

For that reason, we proposed a new form of regulation.' We proposed that a default be established with increased liability exposure for deviations that harm consumers. For lack of a better term, we called this a sticky opt-out mortgage system. A sticky optout system would fall, in terms of stringency, between product regulation and disclosure. For reasons we will explain below, market forces would likely swamp a pure opt-out regime-that is where the need for stickiness came in. This approach corresponds to a combination of changing the rules of the game (top right of table 26.3), and changing liability standards (bottom right of that table).

The proposal is grounded in our equilibrium model of incentives for firms and of individual psychology. Many borrowers may be unable to compare complex loan products and act optimally for themselves based on such an understanding (see, e.g., Ausubel, 1991). We thus deploy an opt-out strategy to make it easier for borrowers to choose a standard product and harder for them to choose a product they are less likely to understand. At the same time, 
lenders may seek to extract surplus from borrowers because of asymnetric information about fiture incomc or detault probabilities (Musto, 2007), and, in the short term, lenders and brokers may benefit from selling borrowvers loans they cannot afford. Thus, a pure detault would be undermincd by the firms, and regulation needs to take account of this market pressurc by pushing back.

In our model, lenders would be required to offer eligible borrowers a standard mortgage (or set of mortgages), such as a fixed-rate, self-anortizing thirty-year mortgage loan or a standard ARM product according to reasonable undcrivriting standards. The precisc contours of the standard set of mortgages would be set by regulation. Lenders would be frec to charge whatever interest rate they ivanted on the loan and, subject to the constraints outlined below, could offer whatever other loan products they wanted outside of the standard package. Borrowers, however, would get the standard mortgage offered, unless they chose to opt out in favor of a nonstandard option offered by the lender, after honest and comprchensible disclosures from brokers or lenders about the termes and risks of the alternative mortgages. An opt-out mortgage system would mean borrowers would be more likely to get straightforward loans they could understand.

But a plain-vanilla opt-out policy is likely to be inadequate. Unlike the savings context, ivhere market incentives align well with policies to overcome behavioral biases, in the context of credit markets, firms often have an incentive to hide the true costs of borrowing. Given the strong market pressures to deviate from the detault offer, we would need to require more than a simple opt-out to make the default stick. Deviation fiom the offer ivould require heightened disclosures and additional legal exposure for lenders in order to make the default sticky. Under our plan, lenders would have stronger incentives to provide meaningful disclosures to those whom they convince to opt out, because they would face increased regulatory scrutiny or increased costs if the loans did not work out.

Future work will need to explore in greater detail the enforcement mechanism. For example, under one potential approach to making the opt-out sticky, if default occurs after a borrower has opted out, the borrower could raise the lack of reasonable disclosure as a defense to bankruptcy or foreclosure. Using an objective reasonableness standard akin to that used for warranty analysis under the Uniform Commercial Code," if the court deternined that the disclosure would not effectively conmunicate the key terms and risks of the mortgage to the typical borrower, the court could modify the loan contract. Although Congress rejected this proposal in the Dodd-Frank
Act, if Congress were to revisit the issuc, it could authorize the CFPB to enforce the requirement on a supervisory basis rather than relying on the courts. The agency would be responsible for supervising the disclosures according to a reasonableness standard and would impose a fine on the lender and order corrective actions if the disclosures were found to be unreas nable. The precise nature of the stickiness re quired and the trade-offs involved in imposing these costs on lenders would need to be explored in greater detail, but in principle, a sticky opt-out policy could effectively leverage the behavioral insight that defaults matter with the industrial organizational insight that market incentives work against the advantages of a pure opt-out policy in many credit markets.

An opt-out mortgage system with stickiness might provide several benefits over current market outcones. For onc, a "plain vanilla" set would be easier to compare across mortgage offers. Information would be more efficiently transmitted across the market. Consumers would be likely to understand the key terms and features of such standardized products better than they would alternative mortgage products. Price competition would be more salient once the features were standardized. Behaviorally, when alternative, "non-vanilla" products are introduced, the consumer would be made aware that these represent deviations from the default, anchoring consumers on the default product and providing some basic expectations for what ought to enter into the choice. Franing the mortgage choice as one between accepting standard mortgage offers and needing af firmatively to choose a nonstandard product should improve consumer decision making. Creditors will be required to make heightened disclosures about the risks of alternative loan products, subject to legal sanction in the event of failure to reasonably disclose such risks; the legal sanctions should deter creditors from making highly unreasonable alternative of fers with hidden and conplicatcd terms. Consumcrs may be less likely to make significant nistakes. In contrast to a pure product regulation approach, the sticky default approach allows lenders to continuc to develop new kinds of mortgages, but only when they can adequately explain key terms and risks to borrowers.

Moreover, requiring a default accompanied by heightened disclosures and increased legal exposure for deviations may help boost high-road lending relative to low-road lending-at least if deviations resulting in harm are appropriately penalized. If of fering an opt-out mortgage product helps to split the market between high- and low-road firms and rewards the former, the market may shift (back) toward firms that of fer home mortgage products that better serve borrowers. For this to work effectively, the default-and efforts to make it sticky - should enable the consumer 
easily to distinguish the typical "good" loan, benefiting both lender and borrower, from a wide range of "bad" loans that benefit the lender with higher rates and fees but harm the borrower; that benefit the borrower but harm the lender; or that harm borrower and lender but benefit third parties, such as brokers.

There will be costs associated with requiring an opt-out home mortgage. For example, sticky defaults may not be sticky enough to alter outcomes, given market pressures. The default could be undermined through the firm's incentive structures for loan officers and brokers, which could provide greater rewards for nonstandard loans. Implementation of the measure may be costly, and the disclosure requirement and uncertainty regarding enforcement of the standard might reduce overall access to home mortgage lending. There may be too many cases in which alternative products are optinal, so that the default product is in essence "incorrect" and comes to be seen as such. The default would then matter less over time, and the process of deviating from it would become increasingly just another burden (like existing disclosure papervork) along the road to getting a home mortgage loan. Lowincome, minority, or first-time homeowners who have benefited from more flexible underivriting and more innovative mortgage developments might see their access reduced if the standard set of mortgages does not include products suitable to their needs.

One could improve these outcomes in a variety of ways. For example, the opt-out regulation could require that the standard set of mortgages include a thirty-year fixed mortgage, a five- or seven-year adjustable-rate mortgage, and straightf orward mortgages designed to meet the particular needs of firsttime, minority, or low-income homeowners. One might develop "snart defaults," based on key borrower characteristics, such as income and age. With a handful of key facts, an optimal default might be offered to an individual borrower. The optimal default would consist of a mortgage or set of mortgages that most closely align with the set of mortgages that the typical borrower with that income, age, and education would prefer. For example, a borrower with rising income prospects might appropriately be offered a five-year adjustable rate mortgage. Smart defaults might reduce error costs associated with the proposal and increase the range of mortgages that can be developed to meet the needs of a broad range of borrowers, including lower-income or first-time homeowvners; however, smart defaults may add to consumer confusion. Even if the consumer (with the particular characteristics encompassed by the smart default) faces a single default product, spillover from options across the market may make decision making more difficult. Finally, it may be difficult to design smart defaults consistent with fair lending rules.
If Congress were to revisit this proposal in the future, it could authorize the CFPB to implement such a program. Supervisory implementation would help to improve the standard mortgage choice set and to reduce enforcement costs over time. The CFPB could be required periodically to reviewv the defaults and to conduct consumer experimental evaluation or survey research to test both the products and the disclosures, so that these stay current with developments in the home mortgage market. Indeed, lenders might be required to conduct such research and to disclose the results to the CFPB and the public upon developing a new product and its related disclosures. In addition, the CFPB might use the results of the research to provide safe harbors or no-action letters for disclosures that are shown to be reasonable ex ante. The CFPB could conduct ongoing supervision and testing of compliance with the opt-out regulations and disclosure requirements. Through such no-action letters, safe harbors, supervision, and other regulatory guidance, the CFPB can develop a body of law that would increase compliance across the diverse financial sectors involved in mortgage lending, while reducing the uncertainty facing lenders from the new opt-out requirement and providing greater freedom for financial innovation.

\section{RESTRUCTURE THE RELATIONSHIP BETWEEN BROKERS AND BORROWERS}

An additional approach to addressing the problem of market incentives to exploit behavioral biases would be to focus directly on restructuring brokers' duties to borrowers and reforming compensation schemes that provide incentives to brokers to mislead borrowers. Mortgage brokers have dominated the subprime market. Brokers generally have been compensated with yield spread premiums (YSP) for getting borrowers to pay higher rates than those for which the borrower would qualify. Such YSPs have been used widely. ${ }^{11}$ In loans with YSPs, unlike other loans, there is a wide dispersion in prices paid to mortgage brokers. As Jackson and Burlingame (2007) have shown, within the group of othervvise comparable borrowers paying YSPs, African Americans paid $\$ 474$ more for their loans, and Hispanics $\$ 590$ more, than white borrowers; thus, even if minority and white borrowers could qualify for the same rate, in practice minority borrowers are likely to pay much more. ${ }^{12}$

Brokers cannot be monitored effectively by borrowers (See Jackson and Burlingame, 2007), and it is dubious that additional disclosures would help borrowers be better monitors (see, e.g., Federal Trade Conımission, 2007), because, among other things, borrowers do not always recognize potential conflicts of interest and because brokers' disclosures of such 
conflicts can paradoxically increase consumer trust (Cain, Locivenstcin, and Moore, 2005). When a broker is seen to divulge that he works for hinself, not in the interest of the borrower, the borrower's trust in the broker may increase: here is a broker who is being honest! Moreover, the subprime mortgage crisis suggests that while in theory creditors and investors have some incentives to monitor brokers, they do not do so effectively.

It is possible to undertake an array of structural changes regarding the broker-borrower relationship. For example, one could alter the incentives of creditors and investors to monitor mortgage brokers by changing liability rules so that broker misconduct can be attributed to lenders and creditors in suits by borrowers (sec Engel and McCoy, 2007). One could directly regulate mortgage brokers through licensing and registration requirements (as is done elsewhere, e.g., in the United Kingdom); recent U.S. legislation, known as the SAFE Act, now mandates licensing and reporting requirements for brokers. In addition, the ex post disclosure standard we suggest might have a salutary effect by making it more costly for lenders when brokers evade disclosure duties, thus generating better monitoring of brokers.

We also suggest that the duties of care that mortgage brokers owe to borrowers should be raised. A higher duty of care would more closely conform to borrower expectations about the role of mortgage brokers in the market. In addition, we support the banning of YSPs that are based on the interest rate charged, for example. Banning YSPs could reduce abuses by eliminating a strong incentive for brokers to seek out higher-cost loans for customers. In fact, a number of lenders moved away from YSPs to fixed fees with some funds held back until the loan has performed well for a period of time, precisely because of broker conflicts of interest in seeking higher YSPs rather than sound loans. Banning YSPs is another way to reinforce high-road practices and protect against a renewed and profitable low-road push to increase market share once stability is restored to mortgage markets. Banning YSPs affects the payoff that brokers receive for mortgage products and thus constitutes a form of scoring change, corresponding to regulation in the bottom right of table 26.3.

\section{PROGRESS UNDER THE DODD-FRANK ACT}

The Dodd-Frank Act fundamentally reforms consumer financial protection policy in the United States. In the mortgage market, the Dodd-Frank Act undertakes a number of steps to regulate the relationship between borrowers and inortgage brokers. For example, the act requires registration and imposes a duty of care on mortgage brokers; bans steering to higher-cost products; and bans YSPs. The act requires that mortgage brokers and lenders assess a borrower's ability to repay based on documented income, taking into account the fully indexed, fully amortizing rate on a mortgage. The act prohibits mandatory predispute arbitration clauses (which linit one's right to access the courts), and it enhances disclosure requirements. It requires the use of escrow of taxes and insurance for higher-cost loans and improves escrow disclosure for all loans. It makes a number of changes to the Home Ownership and Equity Protection Act (HOEPA) to make it more effective and provide greater consumer protection.

The Dodd-Frank Act also puts in place two provisions that foster standardization in the products offered to consumers. The act requires risk retention for securitization of mortgage loans but exempts Qualified Residential Mortgages, which are designed to be standard, high-quality mortgage products with straightforward terms and solid underwriting. For loans falling outside this category that are securitized, the securitizer (or the originator) would need to retain capital to back a portion of the securitization risk. There would thus be a strong incentive to make Qualified Residential Mortgages. The DoddFrank Act also sets out provisions for qualified mortgages, ones for which the ability-to-pay requirement is deemed to be met. In sum, the act defines an approach to the standardization of the terms and underwriting of such mortgages. Lenders making nonqualifed nortgages face a larger potential risk of liability in the event that such loans fail.

More fundamentally, the act put in place the new CFPB to supervise major financial institutions and to set rules and enforce consumer protections across the market. In addition to its authorities to set rules for and enforce existing consumer financial protection laws, the CFPB has the authority to ban unfair, deceptive, or abusive acts or practices. The bureau can also prescribe rules for disclosures of any consumer financial product. In doing so, it will rely on consumer testing, can issue model disclosures that provide a safe harbor for compliance, and nay permit financial institutions to use trial disclosure programs to test out the effectiveness of alternative disclosures to those provided for in the CFPB model form. The Bureau is inandated to merge conflicting mortgage disclosures from the Real Estate Settlement Procedures Act (RESPA) and TILA into a simple form. Consumers are provided with rights to access information about their own product usage in standard, machinereadable formats. Over time, the CFPB may generate research and experimentation that will improve our understanding of consumer financial decision making, and in turn will support the bureau's supervision, rule-writing, and enforcement. 
In addition to these changes to consumer financial protection, the act makes a number of changes to investor protection. For example, it provides the Securitics and Exchange Conmmission (SEC) with authority to engage in investor testing to improve disclosures or other rules. The SEC is authorized to clarify the duties of investment advisors and brokerdealcrs so that they have the samc high standard of care-a fiduciary duty (which, until now, investment advisors had but broker-dealers providing individualizcd investment advice did not). The commission is also authorized to require better disclosures of broker dutics and conflicts of interest and to mandate presale disclosures for investment products. Like the $\mathrm{CFPB}$, the $\mathrm{SEC}$ is authorized to restrict mandatory predisputc arbitration. These changes should naterially advance investor protections consistent with the framework wc have laid out.

\section{Behaviorally Informed Credit Card Regulation}

\section{USING FRAMING AND SALIENCE IN DISCLOSURES TO ENCOURAGE GOOD CREDIT CARD BEHAVIOR}

Credit card companics have fine-tuned product offerings and disclosures in a manncr that appears to be systematically designed to prey on common psychological biases-biases that linit consumer ability to nake optimal choices regarding credit card borrowing (Bar-Gill, 2004). Behavioral econonics suggests that consumcrs underestimatc how much they will borrow and overestimate thcir ability to pay thcir bills in a timely manner, and credit card companics then price their credit cards and competc on the basis of thesc fundannental humlan failings. Nearly $6 \%$ of credit card holders do not pay their bills in full evcry month (Bucks et al., 2006). Moreover, excessivc credit card debt can lcad to bankruptcy (Mann, 2006). Mann (2007) has argued that credit card companies seck to kecp consumers in a "sw'cat box" of distressed credit card debt, paying high fees for as long as possible before finally succumbing to bankruptcy.

The 2005 bankruptcy legislation focused on the need for improved borrower responsibility but paid insufficient attention to creditor responsibility for borrowing patterns. ${ }^{13}$ Credit card companies provided complex disclosures regarding teaser rates, introductory terms, variable rate cards, penalties, and a host of other matters. Both the terms themselves and the disclosures werc confusing to consumers ${ }^{14}$ Credit card companies, it appears, were not conpeting to offer the most transparent pricing.

The Office of the Comptroller of the Currency required national banks to engage in better credit card practices and to provide greater transparency on mininum payments, ${ }^{15}$ and the Federal Reserve proposed changes to its regulations under TILA, partly in the wake of amendments containcd in the bankruptcy legislation. ${ }^{16}$ Under the proposals, for $\mathrm{cx}$ ample, creditors would necd to disclose that paying only the mininum balance would lengthen the payoff timc and interest paid on the credit card; describe a hypothetical examplc of a payoff period paying only the nininum balance; and provide a toll-free number for the consumer to ohtain an estimate of actual payoff timc. ${ }^{17}$ Although the very length and complexity of the board's proposal hints at the difficulty of the task of disclosure to alter consuncer understanding and bchavior, such improved disclosures might nevertheless help.

In earlicr work (Barr, Mullainathan, and Shafir, 2008a), we proposed that Congress could require that minimun payment terms be accompanied by clear statennents regarding how long it would take, and how much interest would be paid, if the customer's actual balance werc paid off in minimum payments, and card companies could be requircd to state the monthly paynent amount that would be required to pay the customer's actual balance in full over some reasonablc period of time, as detcrmincd by regulation. These tailored disclosurcs use framing and salicnce to help consumers, whose intuitions regarding compounding and tining are weak, to make betterinformed borrowing and paynent choices based on thcir specific circumstances. Such an approach would mandate behaviorally informed changes in information disclosurc rules in order to help debias consumers (corresponding to the top right of table 26.3). Although credit card companies have opposed such ideas in the past, disclosures based on the customer's actual balances arc not overly burdensone, as evi denced by their implementation following the CARD Act of 2009.

Disclosures regarding the expected tine to pay off actual credit card balances arc designed to facilitate clcarer thinking but may not be strong cnough to matter. Fven if such disclosure succeeds in shaping intention, we know that there is often a large gap between intention and action. ${ }^{18}$ In fact, borrowcrs would need to change their behavior in the face of strong inertia and marketing by credit card companies, which often propel them to make no more than minimum payments. Morc generally, once cnacted, market players opposed to such disclosures would promptly work to undermine then with countervailing nuarketing and other policies. And there could be occasional costs in other directions: for example, consumers who used to pay more than the amount requircd to pay off their bills in the time frame specified by regulators may now' be drawn to pay off their bills more slowly. Recent prclininary research by Tufano (2009) suggests that the CARD Act may have had this 
mixed effect-improving the outcomes for borrowers who paid more slowly, while wersening the outcomes for those who previously caught up more quickly than the statement's anchor on a payoff flan of three years.

\section{AN OPT-OUT PAYMENT PLAN FOR CREDIT CARDS}

A related approach, intended to facilitate behavior through intention, would be to develop an opt-out payment plan for credit cards under which consumers would need to elect a default payment level meant to pay off their existing balance over a chosen period of time unless the custoner af firmatively opted out and chose an alternative payment at any point. ${ }^{19}$ Consumers could elect to alter their chosen paynent plan in advance or could, with modest friction costs, opt out and change the plan at the time they receive their bill. Such an approach corresponds to changing the rules through opt-out policies (top right of table 26.3). Given what we know about default rules, such payment plans may create expectations about consumer conduct, and in any event, inertia would cause many households simply to follow the initially chosen plan. Increasing such behavior, as driven by prior intentions, could mean lowver rates of interest and fees paid, and lower incidences of financial failure. A chosen opt-out payment plan may also impose costs. Some consumers who, in the absence of the opt-out plan, would have paid off their credit cards sooner, might underestimate their capacity and opt for a slower payment plan, thus incurring higher costs from interest and fees. Alternatively, some consumers may follow their chosen opt-out payment plan when it is unatfordable for them, consequently reducing necessary consumption, such as medical care or sufficient food, or incurring other costly forms of debt. Still, confronting the need to determine a def ault payment plan may force card holders to address the reality of their borrowing and help to alter their borrowing behavior or their payof f plans.

\section{REGULATE LATE FEES}

One problem with the pricing of credit cards is that credit card firms can charge late and over-limit fees with relative impunity because consumers typically do not believe ex ante that they will pay such fees Instead, consumers shop based on other factors, such as annual fees, interest rates, or various reward programs. In principle, firms need to charge late and over-limit fees in order to incentivize customers to avoid late fees and going over their credit limits. In practice, given the high fees they charge, credit card firms are perfectly content to let consumers pay late and exceed their limits.
In earlier work, we proposed changing the scoring of the game (corresponding to a regulatory choice in the bottom right of table 26.3). Under our proposal, firns could deter consumers from paying late or going over their credit card limits with whatever fees they deemed appropriate, but the bulk of such fees would be placed in a public trust to be used for financial education and assistance to troubled borrowers. Firnus would retain a fixed percentage of the fees to pay for their actual costs incurred from late payments or over-linit charges, and for any increased risks of default that such behavior presages. The benefit of such an approach is that it permits firms to deter "bad conduct" by consumers who pay late or go over credit limits but prevents firms from profiting from consumers' predictable nisforecasts regarding their own late payment and over-the-limit behaviors. Firms' incentives to encourage or overcharge for such behaviors would be renoved, while their incentives to deter consumer failures appropriately and cover a firm's costs when they occur would be maintained.

\section{ADVANCES IN THE CARD ACT OF 2009}

The CARD Act of 2009 enacted a number of key changes to the credit card market that take seriously the behavioral insights and the incentives of firms to exploit consumer failings. For example, the CARD Act provides for improvements in plain language disclosures and timing on credit card agreements. It requires credit card companies to notify consumers forty-five days in advance of certain major changes to card ternis, such as interest rates and fees, and it requires that disclosures include information on the time and cost of making only the mininuun payment, as well as the time and cost of paying of $f$ the balance within three years. Moreover, consumers are provided with monthly and year-to-date figures on interest costs and fees incurred, so that they can more readily compare anticipated costs with their actual usage patterns. The act requires firms to obtain consumers' consent-an opt-in-for over-limit transactions. The act bans practices such as certain retroactive rate hikes on existing balances, late fee traps (including mid-day due times, due dates less than twenty-one days after the time of mailing statements, and moving due dates around each month), and double cycle billing. "These practices have in common that consumers cannot readily shape their behavior to avoid the charges; the fees or changes in question are not readily shopped for in choosing a credit card, and disclosures are of little help. Since consumers generally do not understand how payments are allocated across account balances even after improved disclosures (Federal Reserve 2007a,b, 2008), the act requires a consuner's 
payments above the minimum required to be applicd first toward higher-cost balances. In addition, the act takes up the concern with late fees but goes beyond our proposals. Instead, recognizing that consumers do not shop for penalty fees and that they often misforecast their own behavior, it requires that late fees and other penalty fees be "rcasonable and proportionate," as determined by implementing rules; that in any event the fees not be larger than the amount charged that is over the limit or late; and that a late fee or other penalty tee cannot be assessed more than once for the same transaction or event. Furthermore, the act takes steps to make it easier for the market to develop mechanisms for consumer comparison shopping by requiring the public posting to the Federal Rescrve of credit card contracts in machinc-rcadable formats. Private firms or nonprofits can then develop tools for experts and consumers to use to evaluate these various contracts. The CFPB will undoubtedly have occasion to review thesc and other requirements in the future.

\section{Increasing Saving among Low- and \\ Moderate-Income Households}

We have focused in this chapter on improving outcomes in the credit markets using insights from behavioral economics and industrial organization. Our focus derives from the relative lack of attention to this area in the behavioral literature thus far and from the fact that credit markets posc a challenge to approaches that do not pay sufficient heed to the incentives firms have to exploit consumer biases. Savings is another arca ripe for further examination. Whereas much of the behaviorally informed policy work on saving has thus far focused on using defaults to improve retircment saving, many low- and moderate-income (LMI) households have a much greater nced to focus on basic banking services and short-term savings options, services which, for this population, are likely to require a different mix of governmental responses than those in the context of retirement savings for middleand upper-income households.

Many LMI individuals lack access to financial scrvices, such as checking accounts or easily utilized savings opportunities, that middle-income families take for granted. High-cost financial services, barricrs to savings, lack of insurance, and credit constraints increase the economic challenges faced by LMI families. In the short run, it is often hard for these families to deal with fluctuations in income that occur because of job changes, instability in hours worked, medical emergencics, changes in family composition, or a myriad of other factors that cause abrupt changes in economic inflows and outflows. At low income levels, small income fluctuations may create serious problems in paying rent, utilitics, or other bills. Morcover, the high costs and low utility of financial services used by many low-income households extract a daily toll on take-home pay. Limited access to mainstrcam financial services reduces ready opportunities to save and limits families' ability to build assets and save for the future.

In theory, opt-out policies ought to work well among LMI houscholds, as in the retirement world, in encouraging saving. However, while in gencral the market pulls in the same direction as policy in encouraging saving, market forces weaken or break down entirely with respect to encouraging LMI households' saving. This is simply because the administrative costs of collecting small-value deposits are high in rclation to the banks' potential earnings on the relatively small amounts saved, unless the bank can charge high fecs; and with sufficiently high fees, it is not clear that utilizing a bank account makcs economic sense for LMI houscholds. Indeed, the current structure of bank accounts is one of the primary reasons why LMI households do not have them. High minimum balance requircments, high tees for overdraft protection or bounced checks, and delays in check clearance, dissuade LMI houscholds from opening or retaining bank transaction accounts. Moreover, banks usc the private ChexSystem to screen out houscholds who have had difficulty with accounts in the past. Behaviorally insightful tweaks, while helpful, are unlikely to suffice in this context; rather, along with the behavior of consumers who open and maintain them, we need to change the nature of the accounts being offered.

Proposals in this area pertain to changing the rules and the scoring on the left-hand side of table 26.3, where markets may prove neutral to, or even positively inclined toward, the potential reduction of consumer fallibility. We need to figure out how to increase scale and to of fset costs for the private sector to increase saving by LMI familics. We propose three options: a new "gold scal" for financial institutions in return for offering safe and affordable bank accounts; various forms of tax credits, subsidies, or in novation prizes; and a proposal under which the Treasury would direct deposit tax refunds into opt-out bank accounts automatically set up at tax time. 'The proposals are designed to induce the private sector to change their account offerings by offering government inducement to reach scale, as well as to alter consuner bchavior through the structure of the accounts offered. In particular, the government scal of approval, tax credit or subsidy, or bundling through the direct deposit of tax refinds changes the scoring to firms for of fering such products, while the opt-out nature of the proposal and other bchavioral tweaks change the starting rules. 
One relatively "light touch" approach to improving outconces in this arca would be to offer a govcrnment "gold seal" for financial institutions of fering safe and affordablc bank accounts. Whilc the gold seal would not change the costs of the accounts themselves, it might increase the potency of the bank's markcting and thus reduce acquisition costs; also, the goodwill generated might improve the bank's image overall and thus contribute to profitability. Similarly, small prizes for innovation in serving LMI customers might heighten attention to the issue and increase investment in rescarch and development of technology to serve the poor. Grants to local communitics and nonprofits may increase their outreach and inprove the provision of financial coducation and information and help banks and credit unions reach out to LMI customirs.

To overcone the problem of the high fixed costs of offering sensible transaction accounts to low-income individuals with low savings levels, Congress could enact a tax credit for inancial institutions that offer safe and affordable bank accounts to LMI households (B، Irr 2004, 2007). The tax credit would be pay-forperformancc, with financial institutions able to claim tax credits for a fixed amount per account opened by LMI houscholds. The accounts eligible for tax credit could be structured and priced by the private sector according to essential terms required by regulation. For example, costly and incfficicnt checking accounts with a high risk of overdraft would be eschewed in favor of low-cost, low-risk accounts with only debitcard access. The accounts would be debit-card based, with no check-writing capability, no overdrafts permitted, and no ChexSystems rejections for past account failures in the absence of fraud or other meaningfill abusc.

Direct-deposit tax refund accounts could be used to encourage savings and expanded access to banking services, whilc reducing reliance on costly refundanticipation loans and check-cashing services (Barr 2004, 2007). Under the plan, unbanked low-income households who filc their tax returns would have their tax refunds directly deposited into a new account. Direct deposit is significantly chcaper and faster than paper checks, both for the government and for taxpaycr.s. Taxpayers could choose to opt out of the system if they did not want to directly deposit their refund, but the expectation is that the accounts would be widely accepted since they would significantly reduce the costs and expedite the timing of receiving one's tax refund. By using an opt-out strategy and reaching households at tax tince, this approach could help to overconc the tendency to procrastinate in setting up accounts. By reducing the time it takes to receive a refund and pernitting a portion of the funds to bc used to pay for tax preparation, setting up such accounts could help to reduce the incentives to take out costly refund loans, incentives that are magnificd by temporal myopia and misunderstanding regarding the costs of credit. Such accounts would also eliminate the nced to use costly check-cashing scrvices for one's tax refund check. Moreover, the account could continue to be used past tax time. Houscholds could use the account like any other bank account-to reccive their income, save, pay bills, and, of course, to receive their refund in following years. There are a varicty of ways to structure these accounts, all of which would deploy opt-out strategies and government bundling to reach scale and better align the costs of overcoming consuner bias with the shared benefit of moving households into the banking system. Such an approach could efficiently bring millions of houscholds into the banking system.

The power of these initiatives could be significantly increased if it were coupled with a serics of behaviorally informed efforts to improve the take-up of the accounts and the savings outcomes for account holdcrs. For example, banks could encourage employers to endorse direct deposit and autonatic savings plans to set up default rules that would increase savings outcomes. With an automatic savings plan, accounts could be structured so that holders could designate a portion of their paycheck to be deposited into a savings "pocket"; the savings feature would rely on the preconmitment device of autonatic savings, and the funds would be somewhat more difficult to access than those in the regular bank account to make the commitment more likcly to stick. To provide the necessary access to emergency funds in a more cost-effective manner than is usually available to LMI households, the bank account could also include a six-month consumer loan with direct deposit and direct debit, using relationship banking and automated payment systems to provide an alternative to costly payday loans. With direct deposit of income and direct debit of interest and principal due, the loan should be relatively lowrisk and costless for the bank to scrvice. With a longer payment period than in typical payday lending, the loan should be more manageable for consumers living paycheck to paycheck and would likely lead to less repeated borrowing undertaken to stay current on past loans. Moreover, the loan repayment features could also include a provision that consumers "pay themselves first," by including a savings deposit to their account with every payment. Such a precommitment device could overcome the bias to procrastinate in savings and reduce the likclihood of needing future emergency borrowing. All these of forts could increase take up of the banking product and lead to improved savings outcomes. 
The federal government under President Obaina has made some progress toward these objectives over the last couple of years. The Treasury Department has launched pilot programs to test different product attributes, including debit cards and payroll cards, and the FDIC has launched a pilot with a group of banks to test consumer demand and sustainability of a safe and affordable account, using an FDIC template, or gold seal. Finally, the Treasury obtained authorization in the Dodd-Frank Act to experiment with a variety of methods to increase access to bank accounts for lowincome houscholds, including the provision of seed money for research and development into innovative technology and services.

\section{Conclusion}

We have proposed a conceptual framework for behaviorally informed regulation. The framework relies on a more nuanced understanding of human behavior than is found in the classical rational actor model, which underlies much policy thinking. Whereas the classical perspective generally assumes people know: what is important and knowable, that they plan with insight and patience, and that they carry out their plans with wisdom and self-control, the central gist of the behavioral perspective is that people often fail to know and understand things that matter; that they misperceive, misallocate, mispredict, and fail to carry out their intended plans; that the context in which they function has great impact; and that institutions shape defaults, planning, and behavior itself. Behaviorally informed regulation is cognizant of the importance of framing and defaults, of the gap between information and understanding and between intention and action, and of the role of decisional conflict and other psychological factors that affect how people behave. At the same time, we argue, bchaviorally informed regulation needs to take into account not only behavioral insights about individuals but also economic insights about markets.

In this framework, successful regulation requires integrating a more nuanced view of hun an behavior with an understanding of markets. Markets have been shown to systematically favor overcoming behavioral biases in some contexts and to systematically favor exploiting those biases in other contexts. A central illustration of this distinction is the contrast between the market for saving and that for borrowing -in which the same fundamental human tendency to underappreciate the impact of compounding interest leads to opposite market reactions. In the savings context, firms seek to overcome the bias; in the credit context, they seek to exploit it. Our framewerk largely retains the classical perspective of consumers interacting with firms in competitive markets. The difference is that consumers are now understood to be fallible in systematic and important ways, and firms are seen to have incentives to overcome or to exploit these shortcomings.

More generally, firms not only will operate on the contour defined by human psychology but also will respond strategically to regulations. And firms get to act last. Because the firm has a great deal of latitude in issue framing, product design, and so on, they have the capacity to affect consumer behavior and in so doing to circumvent or pervert regulatory constraints. Ironically, firms' capacity to do so is enbanced by their interaction with "behavioral" consumers (as opposed to the hypothetically rational consumers of neoclassical econonic theory), since so many of the things a regulator would find hard or undesirable to control (e.g. frames, design nuance, complexity) can be used to influence consumers' behavior greatly. The challenge of behaviorally informed regulation, therefore, is to envision not only the role of human behavior, but also the ways in which firns are likely to respond to consumer behavior and to the structure of regulation.

We have developed a model in which outcomes are an equilibrium interaction between individuals with specific psychologies and firms that respond to those psychologies within specific markets. These outcomes may not be socially optimal. To the extent that the interaction produces real harm, regulation could address the potential social welfare implications of this equilibrium. Taking both individual psychology and industrial organization seriously suggests the need for policy makers to consider a range of market-contextspecific policy options, including both changing the "rules" of the game, as well as changing its "scoring." We have explored some specific applications of this conceptual frameivork for financial services.

\section{Notes}

1. In addition to incentives to increase savings, employers also seek to boost enployee retention, and they must comply with federal pension rules designed to ensure that the plans are: not "top heary." Moreover, there are significant conıliance issues regarding pensions and retirement plans, disclosure failures, fee churning and complicated and costly fee structures, and conflicts of interest in plan managenent, as ivell as problems with encouraging employers to sign up low-wage workers for retirement plans. Yct, as a comparative matter, market incentives to overcome psychological biases in order to encourage saving are more aligned with optimal social policy than arc market incentives to exacerbate psychological biases to encourage borrowing. 
2. We use this binıodal franewvork of regulatory choicc to simplify the cxploration of how our model of individual psychology and firm incentives affects regulation. We acknowvledge that the regulatory choice matrix is more complex (see Barr, 2005).

3. This is largely because of the existing rcgulatory francivork: pension rcgulation gives enployers incentives to enroll lower-incone individuals in $401(\mathrm{k})$ prograns. Absent thesc, it is likcly that firns would he happy to discourage enrollment since they often must pay the match for these individuals. This point is interesting because it suggests that even defauts in savings only work because somc other regulation "changed the scoring" of the ganee.

4. This example abstracts fron collection costs (which would reduce firms' incentives to hide borroving costs) and instcad focuses on the short-term behavior generally exhibited by lirms, as in the recent home mortgage crisis.

5. In the interests of fisl disclosurc, onc of us (Barr), was the assistant sccretary of the treasury for financial institutions fiom 2009 to 2010 and led the effort to put in place a number of these reforms in the CARD Act, the Dodd-Frank Act, and other Treasury initiatives.

6. See Federal Reserve Board, Final Rule Amending Regulation Z, 12 (.FR Part 226 (July 14, 2008); Summary of findings: Consumer testing of mortgage broker disclosures. Submitted to the Board of Governors of the Federal Reserve System, July 10, 2008 (Retricved from http:// www federalrescrve.gov/ncuscuents/press/bcreg/2008 0714regzconstest.pdf); Federal Reserve Board, Proposed Rule Amending Regulation Z, 72 Fed. Reg.114: 32948 (codilied at 12 C.FR Part 226 [Junc 14, 2007]); Federal Rescrve Board (2007a).

7. Although the financial industry often calls for "principles based" approaches to regulation, in the course of the Dodd-Frank Act lcgislative debatc, the industry strongly resisted this approach, perhaps for these reasons.

8. Ian Ayres recently suggested to us that the burden might be placed on the plaintif fo use consumer survey data to show that the disclosure was unrcasonable, similar to the process used under the Lanhan Act for falsc advertising claims. In individual cases, this might be infeasible, but such an approach might work either for class actions or for clains brought by the C.FPB

9. Again, in the interest of full disclosurc, this proposal was included in the Treasury Department's legislation for the ncw C.FPB but was not included in the final legislation as enacted.

10. See the discussion above relating to the reasonableness standard for disclosurc. As noted above, consumer survey cvidence could be introduced, cither by the CFPB, plaintiffs', or defendants, as to the reasonablencss standard.

11. Sec Jackson and Burlingame (2007). While in principle YSPs could permit lenders legitimatcly to pass on the cost of a mortgage broker fee to a cash-strapped borrower in the form of a higher interest rate rather than in the form of a cash payment, the evidence suggests that YSPs are in fact used to compensate brokers for getting borrowvers to accept higher interest rates, prepayment penalties, and other loan tcrnis.

12. Sec also Guttentag (2000).

13. Sce Bankruptcy Abusc Prevention and Consumer Protection Act of 2005, Pub I. No. 109-8, 119 Stat. 23 (codificd at 11 U.S.C. $\$ 101$ ct seq (2005)).

14. See, e.g., U. S. General Accounting Office (2006).

15. Sec, c.g., Of fice of the Comptroller of the Currency (2003, 2004a, 2004b).

16. Sce Federal Rescrve Board (2007b).

17. Federal Rescrve Board, Proposed Rulc, 12 C.F.K. 226, proposed $\$ .7(b)(12)$, implementing 15 U.S.C. $\$ 1637(b)(11)$.

18. Buehler, Cirif fin, and Ross (2002); Kochler and Poon, (2005).

19. Barr (2007). For a related proposal, sec Gordon and Douglas (2005), in which they argue for an opt-out directdebit arrangement for credie cards.

\section{References}

Adkins, N. R., and Ozanne, J. L. (2005). The low literate consumer. Journal of Consumer Research, 32, 93-105.

Alcxander, (i. J., Joncs, J. 1)., and Nigro, P. J. (1998). Mutual find sharcholders: Characteristics, investor knowledge and sources of information. Financial Services Review, 7, 301-316.

American Payroll Association. (2002). Survey results: American Payroll Association 2003 Direct Deposit Survey. Retrieved from http://legacy.anıericanpayroll .org/pdts/paycard/DDsurv_results0212.pdf

Arkes, H. R., and Blumer, C. (1985). The psychology of sunk cost. Organizational Behavior and Human Decision Processes, 35,124-140.

Ausubel, L. M. (1991). The failure of conpetition in the credit card market. American Economic Review, 81, 50-81.

Bar-Gill, . (2004). Seduction by plastic. Nortbwestern University Law Review, 98(4), 1373-1434.

Barr, M. S. (2004). Banking the poor. Yale Journal on Regulation, 21(1), 121-237.

. (2005). Modes of credit narket rcgulation. In N. Retsinas and F. Belsky (Eds.), Building assets, Building credit (pp. 206-236). Washington, DC: Brookings Institution Press.

- (2007). An inclusive, progressive national savings and financial scrvices policy. Harvard I aw and Policy Review, I(1), 161-184

Barr, M. S., Mullainathan, S., and Shafir, E. (2008a). Behaviorally informed financial services regulation. White paper. Washington: Ncw Amcrica Foundation. 
- (2008b). Behaviorally informed home mortgage credit regulation. In N. Retsinas and E. Belsky (Eds.), Borrowing to live: Consumer and mortgage credit revisited (pp. 170-202). Washington, DC: The Brookings Institution.

. (2008c). An opt-out home mortgage system. Hamilton Project Discussion Paper 2008-13. Washington, DC: Brookings Institution.

- (2009). The case for bchaviorally informed regulation. In D. Moss and J. Cistcrnino (Eds.), New perspectives on regulation (pp. 25-62). Cambridgc, MA: The Tobin Project.

Bell, 1). E. ( 1982). Regret in decision making under uncertainty. Operations Research, 30, 961-981.

Benartzi, S., and Thaler, R. H. (2004). Save more tonorrow: Using behavioral cconomics to increase cinployec saving. Journal of Political Economy, 112 (1-2), 164-187.

Berry, C. (2004). To bank or not to bank? A survey of lowincomc households. Working Paper Scries. Cambridgc, MA: Joint Center for Housing Studics.

Bertrand, M., Karlan, D., Mullainathan, S., Shafir, E., and Zinman, J. (2010). What's advertising content worth? Evidence from a consumer credit marketing ficld experiment. Quarterly Journal of Economics, 125(1), 263-305

Bucks, B. K., Kcnnickell, A. B., and Moore, K. B. (2006). Recent changes in U.S. family finances: Evidence from the 2001 and 2004 Survey of Consumer Finances. Fedcral Rescrve Bulletin, 92. Retricved from http:// uww. fedcralreservc.gov/pubs/bulletin/2006/finance survey.pdf

Buchler, R., (iriffin, D., and Ross, M. (1994). Exploring the "planning fallacy": Why pcopic underestimate their task completion tincs. Journal of Personality and Social Psychology, 67, 366-381.

- (2002). Inside the planning fallacy: The causes and consequences of optimistic time predictions. In T. (iilovich, 1). (iriffin, and D. Kahncman (Eds.), Heuristics and biases: The psychology of intuitive judgment (pp. 250-270). Cambridge: C.ımbridge University Press.

Cain, D. M., (i. Locwenstein, and 1). A. Moore. (2005).

The dirt on coning clcan: Perverse effects of disclosing conflicts of intcrest. Journal of Iegal Studies, $34(1), 1-25$

Cialdini, R. B., Cacioppo, J. T., Bassett, R., and Miller, J. A. (1978). Low-ball procedure for producing compliance: Commitment then cost. Journal of P'ersonality and Social Psychology, 36, 463-476.

Darley, J. M., and Batson, C.. 1). (1973). From Jcrusalem to Jcricho: A study of situational and dispositional variables in helping behavior. Journal of Personality and Social Psychology, 27, 100-108.

Edin, K., and Lcin, L. (1997). Work, welf arc, and single mothers' cconomic survival strategies. American Sociological Review, 62(2), 253-266.

Engcl, K., and McCoy, P. (2007). Turning a blind cyc: Wall Street finance of predatory lending. Fordham Law Review, 75, 2039-2103.

Federal Reserve Board. (2007a). Design and testing of ef. fective truth in lending disclosures. Retrieved from http://www.fcderalreserve.gov/dcca/rcgulatione/ 20070523/Execsummary.pdf . (2007b). Proposed amendments to Regulation Z (press relcasc). Retrieved from http://ntww.tedcral reserve.gov/BoardDocs/Press/boreg/2007/2007 $0523 /$ default.htm

-._. (2008). Design and testing of effective truth in lending disclosures: Findings from experimental study. Retrieved from http://www.federalrescrvc.gov/news cvents/press/bcreg/bcreg20081218a8.pdf

Federal lirade Commission. (2007). Improving consumer mortgage disclosures: An empirical assessment of current and prototype disclosure forms. Burcau of Econonics Staff Report, Federal Trade Comnission, Washington, DC. Retricucd fron http://wwiv.ftc.gov/os/007/06/ P()25505mortgagedisclosurcreport.pdf

Frecdman, J. L., and Fraser, S. C. (1966). Compliance without pressure: The foot-in-the-door technique. Journal of Personality and Social Psychology, 4, 195-203.

Gordon, R., and Douglas, 1). (2005, December). Taking charge. Washington Monthly. Retricved from http:// www rvashingtonmonthly.com/f catures/2005/05 12 gordon.htinl

Gourville J. 'l., and Soman, 1). (1998). Payment depreciation: The bchavioral effects of temporally scparating payments from consumption. Journal of Consumer Research, 25, 160-174.

Guttentag, J. (2000). Another view of predatory lending. Working Paper 01-23-B. Wharton Financial Institutions Center, Philadelphia, PA. Retrieved fiom http:// fic. wharton.upenn.edu/fic/papers/01/0123.pdf

Iycngar, S. S., Jiang, W., and Huberman, (i. (2004). How much choice is too much: Detcrminants of individual contributions in $40 \mathrm{l}(\mathrm{k})$ retircment plans. In (). S. Mitchell and S. Utkus (Eds.) Pension design and structure: New lessons from behavioral finance (pp. 83-97). Oxford: Oxtord University Press.

Iyengar, S. S., and Iepper, M. R. (2000). When choice is demotivating: Can one desire too much of a good thing? Journal of Personality and Social Psychology, 79, 995-1006.

Jackson, H. E., and Burlinganc, L. (2007). Kickbacks or compensation: The case of yicld spread premiums. Stanford Journal of Jaw, Business and Finance, 12, 289-361.

Johnson, E. J., and Goldstein, 1). (2003). Do def aults save lives? Science, 302, 1338-1339. 
Johnson, E. J., Hershey, J., Meszaros, J., and Kunreuther, H. ( 1993 ). Framing, probability distortions, and insurance decisions. Journal of Risk and Uncertainty, $7,35-51$

Kahneman, D. (1994). New challenges to the rationality assumption. Journal of Institutional and Theoretical Economics, 150, 18-36.

Kahneman, D., and Tversky, A. (1979). Prospect theory: An analysis of decision under risk. Econometrica, 47, 263-291.

Kennedy, D. (2005). Cost-bencfit analysis of debtor protection rules in subprime inarket def ault situations. In N. Retsinas and F. Belsky (Eds.), Building assets, building credit (pp. 266-282). Washington, DC: Brookings Institution Press.

Kinetsch, J. L. (1989). The endorvment effect and cvidence of nonreversible inditfercnce curves. American Economic Review, 79, 1277-1284.

Kochler, D. J., and C.S.K. Poon. (2005). Self-predictions overweight strength of current intentions. Journal of Experimental Social Psychology, 42(4), 517-524.

Koide, M. (2007, November 16). The assets and transac tion account. New America Foundation. Retrieved from http://newvamerica.net/publications/policy/ assets_and_transaction_account

Lepper, M. R., Greene, D., and Nisbett, R. E. (1973). Undermining children's intrinsic interest with extrinsic rcivard: A test of the "overjustification" hypothesis. Journal of Personality and Social Psychology, 28, 129-137.

I.ewin, K. (1951). Intention, will and necd. In D. Rapaport (Ed.), Organization and patbology of thought: Selected sources. (pp. 95-153). New' York: Columbia University Press.

Lichtenstein, S., and Slovic, P. (Eds.) (2006). The construction of preference. Cambridge: Cambridge University Press.

Loewenstein, G., and Flster, J. (Eds.) (1992). Choice over time. New York: Russcll Sage Foundation.

Loewenstein, G. and Thaler, R. H. (1992). Intertemporal choice. In R. H. Thaler (Ed.), The winner's curse: Paradoxes and anomalies of economic life. New York: Free Press.

Lusardi, A., Mitchell, -., and Curto, V. (2009). Financial literacy and financial sophistication among older Americans. NBER Working Papcr No. 15469 National Bureau of Economic Research.

Madrian, B. C., and Shea, D. F. (2001). The power of suggestion: Incrtia in $401(\mathrm{k})$ participation and savings behavior. Quarterly Journal of Economics, 116(4), 1149-1187.

Mann, R. (2006). Charging abead: The growth and regulation of payment card markets. Cambridge: Cambridge University Press.
(2007). Bankruptcy retorm and the sweat box of credit card debt. University of Illinois Law Review, 2007(1), 375-403.

Milgran, S. (1974). Obedience to authority. New York: Harper and Row.

Mullainathan, S. and Shafir, E. (2009). Savings policy and decision-making in low-income households. In M. Barr and R. Blank (Eds.), Insufficient funds: Savings, assets, credit and banking among low-income bousebolds (pp. 121-145). New York: Russell Sage Foundation.

Musto, D. K. (2007). Victiwizing the borrowers: Predatory lending's role in the subprime mortgage crisis. Working paper, Wharton School, University of Pcnnsylvania. Retrieved from http://knowledgewharton.upenn .edu/article.cfm?articleid=1901

Office of the Comptroller of the Currency. (2003). Account management and loss allowance guidance. (CC) Bull. 2003-1. Retrieved from http://www.occ.gov/newsissuances/bulletins/2003/bulletin-2003-I html (2004a). Secured credit cards. OCC: Advisory l.etter 2004-4. Retricved from http://www.occ.gov/ static/news-issuances/memos-advisory-letters/2004/ advisory-letter-2004-4.pdf

. (2004 b). Credit card practices. OCC Advisory Letter 2004-10. Retrieved from http://www.occ gov/static/news-issuances/nemos-advisory-letters/ 2004/advisory-letter-2004-10.pdf

Redelmeier, D., and Shafir, E. (1995). Medical decision making in situations that offer multiple alternatives. Journal of the American Medical Association, 273(4), 302-305.

Sanuuelson, W., and Zeckhauser, R. J. (1988). Status quo bias in decision making. Journal of Risk and Uncertaint $y, 1,7-59$

Schuitz, E. ( 1995, December 22). Helpful or conf using? Fund choices multiply for many retircincnt plans. Wall Street Journal, pp. C: 1, C:25

Shafir, E., Simonson, 1., and Tversky, A. (1993). Reasonbased choice. Cognition, 49, 11-36.

Sherraden, M., and Barr, M. (2005). Institutions and inclusion in savings policy. In N. Retsinas and E. Belsky (Eds.), Building assets, building credit (pp. 286-31 5) Washington, DC: Brookings Institution Press.

Thaler, R. H. (1985). Mental accounting and consumer choice. Marketing Science, 4, 199-214.

-- _ (1992). The winner's curse: Paradoxes and anornalies of economic life. New York: Free Press.

--_ (1999). Mental accounting matters. Journal of Bebavioral Decision Making, 12(3), 183-206.

Thaler, R. H., and Sunstein, C. R. (2008). Nudge: Improving decisions about bealth, wealth, and happiness. New Haven, CT: Yale University Press.

Tufano, P. (2009). Consumer financc. Annual Review of Financial Economics, 1, 227-247. 
Tversky, A., and Kahneman, D. (1991). Loss aversion in riskless choicc: A rcficrnce dependent nodel. Quarterly Journal of Economics, 106, 1039-1061.

Tversky, A., and Shafir, E. (1992). Choice under conflict: The dynamics of deferred decision. Psycholo gical Science, 3, 358-361.

U.S. General Accounting Otfice. (2006). Credit cards: Increased complexity in rates and fees heightens the need for more effective disclosures to consumers. Report
06-929. Retrieved from http://ww.gao.gov/new .itcms/d06929.pdf

Warren, E. (2007). Unsate at any ratc. $D E M() C R A(Y: A$ Journal of Ideas, 5 . Retrieved from http://ww .democracyjournal.org/5/6528.php

Whitc, J. J., and Summers, R. S. (1995). Uniform commercial code, 4th ed. Practitioner Trcatise Series. St. Paul, MN: Wcst Publishing. 